\title{
Human Capital and Economic Growth in Morocco: Evidence from Bayesian Model Averaging
}

\author{
Omar Essardi ${ }^{1} \&$ Redouane Razzouk ${ }^{1}$ \\ ${ }^{1}$ Faculty of Law, Economics and Social Sciences, Cadi Ayyad University, Morocco \\ Correspondence: Omar Essardi, Faculty of Law, Economics and Social Sciences, Cadi Ayyad University, \\ Morocco, PO Box 2380 Daoudiate, Marrakesh, Morocco.
}

Received: August 28, 2017

doi:10.5539/ibr.v10n12p167
Accepted: October 10, 2017

Online Published: November 16, 2017

URL: https://doi.org/10.5539/ibr.v10n12p167

\begin{abstract}
The paper investigates the relationship between human capital and economic growth in Morocco during the period from 1965 to 2015. In order to test this relationship we estimated a growth function using firstly the Johansen multivariate cointegration test and the Granger causality test. Secondly, we used the method of the Bayesian Model Averaging (BMA) that takes into consideration the uncertainty related to the specification of the model studied. In the theoretical literature, the difficulty of measuring human capital is often stressed. In order to overcome this problem, we use four proxies of human capital: first, we employ the average years of schooling. Second, we use the index of the gap in life expectancy between Morocco and de veloped countries. Third, we integrate the qualitative aspects of education and health by constructing two composite indicators of human capital using Principal Component Analysis (PCA) method.
\end{abstract}

The main results of regression analysis confirm that in the specification of determinants of GDP per worker the average years of total schooling, the life expectancy index and the indicator of quality of health affect positively and significantly level of GDP per worker. However, in the specification of determinants of the growth of the GDP per worker, we found there is no proxy of human capital that affects significantly the growth of the GDP per worker.

In addition, the results of Granger causality test show that only the indicator of quality of health that cause the GDP per worker. As well, these results show that the average years of total schooling and the indicator of quality of education cause the growth of GDP per worker. We suggest that the Moroccan authorities should make additional efforts to raise the level of quality of human capital especially in the health sector and increase the productivity of both public and private investment.

Keywords: human capital, economic growth, Bayesian Model Averaging (BMA), Principal Component Analysis (PCA)

\section{Introduction}

The importance of human capital into economic growth goes back to the works of (Smith, 1795) who stated that "training in its all forms improve productivity which contributes to economic expansion"

The debate on this relationship was developed, in the first place, thanks to the works of the designers of the theory of human capital ( (Mincer, 1958), (Schultz, 1961), (Becker, 1962) and (Denison, 1962)), which they investigated the impact of human capital through its influence on the workers productivity. After that, the works of theorists of the models of endogenous growth enriched this debate ( (Romer, 1986), (Lucas, 1988), (Barro, 1991), (Mankiw et al., 1992)), they integrate the human capital as determinant of economic growth.

The empirical studies related to models of endogenous growth confirm that differences in stock of human capital could explain differences of production growth between countries, see ( (Barro, 1991), (Mankiw et al., 1992), (Barro \& others, 2003))).

In the empirical studies, we detect three mechanisms by which human capital may influence economic growth:

1. The increase in the stock of human capital by promoting education and health can increase the workers productivity, which in turn increases the productive capacity of the national economy ( (Schultz, 1961), (Mincer, 1974), (Mankiwet al., 1992)). 
2. The increase in stock of human capital can influence the workers productivity by promoting innovation and using the new technologies ( (Nelson \& Phelps, 1966), (Romer, 1990), (Aghion \& Howitt, 1992), (Benhabib \& Spiegel, 1994)).

3. The stock of human capital can be an important determinant for the attraction of foreign direct investment inflows ( (Noorbakhsh et al., 2001), (Koukpo, 2005), (Bouoiyour et al., 2009)).

However, with the improvement of data quality and the application of more sophisticated econometric methods, some authors concluded that the effects of the human capital on economic growth are negatives and sometimes not significant ( (Islam, 1995), (Caselli et al., 1996), (Dessus, 2000), (Pritchett, 2001)).

Pritchett (2001) provided three interpretations to explain the controversial results on the effects of human capital in economic growth: First, he supposes that the institutional framework does not encourage positive externalities of human capital on economic performance. Second, he believes that the quality of education may be low despite of the increase in the years of education. Finally, he considers that low demand of educated workers could characterize the labor market, which reduces the excepted human capital benefits.

In September 2000, as part of 189 countries that signed the United Nations Millennium Declaration, Morocco government has engaged to achieve eight development goals and de veloped countries are engaged to support poor countries to achieve these objectives. Among the eight objectives four are directly linked to human capital: to ensure primary education for all, to reduce child mortality, to improve maternal health, to defeat HIV/AIDS, malaria and other diseases, and the others objectives contribute to the improvement of human capital: reducing extreme poverty and hunger and promoting gender equality.

In order to achieve these objectives, Morocco has engaged in many reforms in the sectors of education and health. On the one hand, the reforms of the Moroccan educational system started by the adoption in 1999 of the National Charter for Education and training. After that, authorities take on the emergency program for the period from 2009 to 2012 and they launched in 2015 a new strategy of teaching called "vision 2030".On the other hand, authorities in health sector applied the basic medical coverage through the generalization of the medical assistance schema in 2012 and launching health strategy for next four years.

The main objective of this paper is to test first the long-run dynamic relationship between Moroccan economic growth and human capital by using Johansen multivariate cointegration test and the Granger causality test. Secondly, we use the method of (BMA) which takes into account the uncertainty related to the specification of the model studied.

We will organize the paper as the following: we will start by presenting a review of the empirical studies. Then we present the macroeconomic conditions and indicators of in Moroccan human capital after that we present the empirical approach, data sources and variables used. Afterward we discuss the results obtained finally we come up with conclusion.

\section{Review of the Empirical Studies}

Human capital is at the heart of empirical works that explain the determinants of economic growth. Aghion \& Howitt (1998) point out that the authors follow two main approaches to quantify human capital and its impact on economic growth. Some authors consider human capital as flow variable in the process of accumulation is just as physical capital (((Lucas, 1988), (Romer, 1989),(Barro, 1991),(Mankiw et al., 1992))). Other authors consider it a variable stock and when it is high, the country's production processes could benefit from the positive externalities related using innovation and new technologies ((Barro \& Lee, 1994),(Benhabib \& Spiegel, 1994),(Bloom \& Mahal, 1995)).

Recent works has followed three main research directions. In the first direction, authors have enriched the endogenous growth model by introducing in addition to the basic model variables other variables related to health conditions, institutions and free trade policy ( (Berthélemy et al., 1997), (Abdouni \& Hanchane, 2008), (Mansouri, 2009) and (Bouoiyour et al., 2009)). On the second research direction, some authors have used more sophisticated econometric methods because studies that rely on cross section data has been criticized (GMM panel data, Bayesian approach ...) ( (Fall \& Thiaw, 2012), (Leon-Gonzalez \& Vinayagathasan, 2015), (Fetahi-Vehapi et al., 2015) and (Mbulawa, 2015)). The authors of the third research direction have introduced the role of quality education in explaining growth ( (Hanushek \& Kimko, 2000), (Barro \& Lee, 2001), (Altinok \& Murseli, 2007), (Hanushek \& Woessmann, 2012), (Altinok et al., 2014)).

The existing theoretical literature argues that human capital may interact positively and significantly to economic growth. Howe ver, several empirical studies obtained controversial results. Many authors like (Dessus, 2000), (Kruger \& Lindahl, 2001), (De la Fuente \& Doménech, 2002), (Altinok \& Murseli, 2007), (Sunde \& Vischer, 
2011), (Schoellman, 2011)confirmed that many studies fail to measure the impact of human capital on the economic growth because they use weak proxies of different dimensions of human capital.

In the other hand, two categories of empirical studies characterized the Moroccan context: studies based on time series data and the studies based on the panel data as part of the countries of the region of MENA or countries of South Mediterranean.

Bouayad (1994) to investigate the relationship between the growth rate of GDP and social expenditures related to the education and health sectors using the tests of causality and cointegration. He shows that GDP reacted positively to changes in social spending for a period from 1950 to 1985.

Bouoiyour (2000) in a study that takes into account the data covering the period from 1958 to 1994 and approximating human capital by the rate of primary and secondary schooling, has concluded that there is bidirectional causality between education and growth in the short term but not confirmed in the long term.

Besides, Bouoiyour \& Bennaghmouch (2002) in a study that considers the period from 1975 to 1995 and measuring human capital by the years of education at primary, secondary and higher level. They conclude the presence of a significant positive effect of education on economic growth. But, this effect reduces when the level of education increases.

Ibourk \& Amaghouss (2013) in a study that covers the period from 1975 to 2010 and takes into account data from 15 countries in the MENA region fragmented into two categories: countries with high-income level and countries with an average income level estimated a growth function. They approximate human capital through several proxies including the literacy rate, primary, secondary and higher school enrollment, the average years of school at primary education and secondary, the number of students per teacher and life expectancy. They show that the impact of education on growth is positive but it depends on the level of group of countries studied income.

In addition, Sbaouelgi(2015) in a comparative analysis of three different countries including Morocco, Tunisia and Korea, she investigates the relationship between human capital and economic growth approximating human capital through three proxies: expenditure per student as a percentage of GDP per capita, the number of graduates in science and engineering and the gross rate of higher education enrollment. In addition, she applied the causality tests and co-integration between these indicators and economic growth. She concluded the absence of a long-term relationship for the cases of Tunisia and Morocco. Nevertheless, the case of South Korea is characterized by a long-term relationship, which justifies the development gap between these countries.

In sum, despite the variety of measures used to approximate the human capital in the Moroccan context, realized empirical work offers an assessment concluding that there is positive impact of human capital on economic growth.

\section{Macroeconomic Conditions and Indicators of Human Capital in Morocco}

Since independence, Morocco has implemented several social and economic policies to ensure the integration of the Moroccan economy in the way of development. We distinguish three periods of reforms: the period between 1965 and 1983, authorities made strong intervention in the economy to restructure the industrial sector and substitute products importation by local production. During the period between 1985 and 1999, the Moroccan economy has seen the introduction of the structural adjustment plan under the advices of international financial institutions, which made significant impact concerning the increase of the rate of growth, the control of inflation and the improving of trade terms. However, the expected results are insufficient in particular with respect to the reduction of poverty and inequality.

The period between 2000 and 2015 was marked by social and economic reforms focused on several levers: Improving working conditions with the new labor code established in 2003. Modernization of industrial, agricultural fabric and promotion of exportations because authorities implemented emergence plan in 2005 and applied the green plan since 2007. Improving well-being and social stability with the measures of the National Human Development Initiative1 (NHDI) in 2005. Introduction of program of Assistance medical Obligatory (AMO) in (2005) and generalization of medical assistance scheme since 2011.

Besides, despite the vulnerability of agricultural production to climatic conditions ( (Mansouri, 2009)).The Moroccan economy has grown steadily in the past two decades with an average growth rate, which reached $4.65 \%$ in the period 1996-2005 and 4,38\% in the period 2006-2015. The inflation rate is at an average rate of 1.6 during

\footnotetext{
${ }^{1}$ NHDI, which mean by French INDH: “Initiative National de Développement Humain”.
} 
the period between 2006 and 2015. The investments rate increased from 29, $4 \%$ to 34, 2 also the rate of unemployment decreased from $12 \%$ to $9,8 \%$ during the same period. Many economists agree that these performances are due to the emergence of new motor trades of growth including automotive, electrical and electronic, aeronautics industries and offshoring.

However, the Moroccan economy faces four constraints: first, the total external debt to GDP is high; it has decrease less from 41.82 to 32.98 on average during the last 10 years. Secondly, the trade deficit continued to extend going from $-3.66 \%$ of GDP on average for 1996-2005 to $-11,34 \%$ of GDP on average for the period 2006-2015. Thirdly, despite increase of investment rate, this capital has less productivity and it is concentrated in just two sector industry and building sectors. In the end, Morocco suffers from a problem of unemployment, which is high.

As to conditions of human capital indicators, the proportion of the illiterate population in the population aged more than 15 years has decreased significantly. However, Morocco is characterized by the highest rate in the region of MENA with a percentage of $42.1 \%$ in 2015.

By examining the database of (Barro \& Lee, 2016) from 1965 to 2015, we identify that the evolution of the average years of schooling in Morocco is characterized by a steady growth. It varied from 0.28 in 1965 to 3.41 in 2015 at the level of primary education, from 0.19 to 1.6 at the secondary education and 0.01 to 0,37 at the level of higher education.

Also, the resources that have been allocated to the sector of education which were 4.51 percent of GDP during the period 1986-1990 they rose to 6.72 during the period 2011-2015; this increase is faster at the heading of personnel and material expenses.

Despite the progress made over the past two decades, the public offering of education in Morocco has many problems: first, the rate of alphabetization is the highest in the North Africa region with a percentage of $42,1 \%$. Second, according to (UNESCO, 2016), the rate of drop out and repetition rate in primary and secondary education is very high. Third, according to results of Mathematics and Science related to achievement tests the quality of education is very low comparing to other countries in MENA region.

In the health sector, comparing Morocco to Tunisia, Algeria, Jordan and Egypt in terms of indicators related to expenditure on health per capita and the infant mortality rate per 1000 live births, we realize that Morocco needs much efforts to invest in this respect.

Moreover, according to (BAD, 2013), only $50 \%$ of Moroccans have the basic medical coverage. Besides, in the report of (CESE, 2013) ${ }^{2}$ showed that the share of health expenditures directly supported by Moroccan households is $53.6 \%$, which mean that an average amount of 802 dirham per capita annually. This amount does not include additional fees related to transportation and accommodation. Furthermore, the rate of infant mortality remains high, particularly in rural areas, (Rural 35.3 and Urban 25.3 per thousand born) and the maternal mortality rate in rural areas is two times higher than urban areas. This calls into question the quality of care offered by this sector.

By and large, we can conclude that despite the progress made over the past two decades, the public offering of health and education doesn't respond to the huge needs of people therefore, the stakeholders are called invest more so as to live up to citizens' expectations.

\section{The Empirical Approach}

To investigate the relationship between human capital and economic growth in Morocco we estimated a growth function relying in (Mankiw et al., 1992) specification. We propose to extend this equation in two steps: first, we take into account the effects of the health dimension, based on the works of (Knowles \& Owen, 1995) and (Ram, 2007). Secondly, we take into account the effects of the qualitative dimension of human capital, based on the work of (Boccanfuso et al., 2009).

To measure impact of human capital in the economic growth, we propose to use the method of the Bayesian Model Averaging, which takes into account the uncertainty related to the specification of the model studied.

\subsection{Specification of the Empirical Model}

Mankiw et al. (1992) propose the Cobb Douglas production function developed by human capital following the form:

${ }^{2}$ Consul Economic, Social and Environment, which means by French CESE: "Conseil économique, social et environnemental (CESE)". 


$$
Y_{t}=K_{t}^{\alpha} H_{t}^{\beta}\left(A_{t} L_{t}\right)^{1-\alpha-\beta}
$$

Where $Y_{t}$ is gross domestic product at time $t, \alpha$ and $\beta$ denotes the elasticity of production in relation to changes in the physical capital stock $\mathrm{K}_{\mathrm{t}}$ and the stock of human capital $\mathrm{H}_{\mathrm{t}}, \mathrm{A}_{\mathrm{t}}$ represents technological progress and $\mathrm{L}_{\mathrm{t}}$ denotes the quantity of labor, considering :

$$
\mathrm{y}_{\mathrm{t}}=\frac{\mathrm{Y}_{\mathrm{t}}}{\mathrm{A}_{\mathrm{t}} \mathrm{L}_{\mathrm{t}}} ; \mathrm{k}_{\mathrm{t}}=\frac{\mathrm{K}_{\mathrm{t}}}{\mathrm{A}_{\mathrm{t}} \mathrm{L}_{\mathrm{t}}} \text { And } \mathrm{h}_{\mathrm{t}}=\frac{\mathrm{H}_{\mathrm{t}}}{\mathrm{A}_{\mathrm{t}} \mathrm{L}_{\mathrm{t}}}
$$

We write the previous equation as follows:

$$
\mathrm{y}_{\mathrm{t}}=\mathrm{k}_{\mathrm{t}}^{\alpha} \mathrm{h}_{\mathrm{t}}^{\beta}
$$

With $y_{t}$ corresponds to the quantity of output per effective unit of labor at period $t$.

As in the Solow model, Mankiw et al. (1992) suppose that $L_{t}$ and $A_{t}$ progress to an exogenous growth rate $n$ and $g$ and the dynamics of factor accumulation are determined by:

$$
\left\{\begin{array}{l}
\dot{\mathrm{k}}_{\mathrm{t}}=\mathrm{s}_{\mathrm{k}} \mathrm{y}_{\mathrm{t}}-(\mathrm{n}+\mathrm{g}+\delta) \mathrm{k}_{\mathrm{t}} \\
\dot{\mathrm{h}}_{\mathrm{t}}=\mathrm{s}_{\mathrm{h}} \mathrm{y}_{\mathrm{t}}-(\mathrm{n}+\mathrm{g}+\delta) \mathrm{h}_{\mathrm{t}}
\end{array}\right.
$$

$k_{t}$ is the rate of the physical capital stock growth while $s_{k}$ is the share of income invested in physical capital, $h_{t}$ is the rate of human capital stock growth whereas $s_{h}$ is the share invested in human capital, $\mathrm{n}$ is the rate of the active population growth, which $g$ is the rate of technological progress growth and $\delta$ is the rate of human capital depreciation identical to that of physical capital.

Considering that yields of production factors are decreasing $(\alpha+\beta<1)$, the level of human capital and physical capital in the steady state is:

$$
\left\{\begin{array}{l}
\mathrm{k}^{*}=\left(\frac{\mathrm{s}_{\mathrm{k}}^{1-\beta} \mathrm{s}_{\mathrm{h}}^{\beta}}{\mathrm{n}+\mathrm{g}+\delta}\right)^{\frac{1}{1-\alpha-\beta}} \\
\mathrm{h}^{*}=\left(\frac{\mathrm{s}_{\mathrm{k}}^{1-\alpha} s_{\mathrm{h}}^{\alpha}}{\mathrm{n}+\mathrm{g}+\delta}\right)^{\frac{1}{1-\alpha-\beta}}
\end{array}\right.
$$

We substitute these two values into the production function and we introduce this latter to logarithm. Then, we obtain the following specification:

$$
\ln \frac{Y_{t}}{L_{t}}=\ln A_{0}+g t-\frac{\alpha+\beta}{1-\alpha-\beta} \ln (n+g+\delta)+\frac{\alpha}{1-\alpha-\beta} \ln \left(s_{k}\right)+\frac{\beta}{1-\alpha-\beta} \ln \left(s_{h}\right)
$$

Mankiw et al. (1992) state that if we suppose that $(\alpha+\beta=1)$ the equation mentioned above is transformed to an endogenous growth function.

The rate of convergence towards the level of income per capita of steady equilibrium is given by:

$$
\frac{\mathrm{d} \ln \left(\mathrm{y}_{\mathrm{t}}\right)}{\mathrm{dt}}=\frac{\dot{\mathrm{y}}}{\mathrm{y}}=\lambda\left[\ln \left(\hat{\mathrm{y}}^{*}\right)-\ln \left(\mathrm{y}_{\mathrm{t}}\right)\right]
$$

With

$$
\lambda=(n+g+\delta)(1-\alpha-\beta)
$$

This implies that:

$$
\ln \left(\mathrm{y}_{\mathrm{t}}\right)=\left(1-e^{-\lambda t}\right) \ln \left(\mathrm{y}^{*}\right)+e^{-\lambda t} \ln \left(\mathrm{y}_{0}\right)
$$

Consider subtracting $\ln \left(\mathrm{y}_{0}\right)$ from each member of the above equation we find:

$$
\ln \left(\mathrm{y}_{\mathrm{t}}\right)-\ln \left(\mathrm{y}_{0}\right)=\left(1-e^{-\lambda t}\right) \ln \left(\mathrm{y}^{*}\right)-\left(1-e^{-\lambda t}\right) \ln \left(\mathrm{y}_{0}\right)
$$


By substitutingy*, we deduce:

$$
\begin{gathered}
\ln \left(\mathrm{y}_{\mathrm{t}}\right)-\ln \left(\mathrm{y}_{0}\right)=-\left(1-e^{-\lambda t}\right) \ln \left(\mathrm{y}_{0}\right)-\left(1-e^{-\lambda t}\right) \frac{\alpha+\beta}{1-\alpha-\beta} \ln (n+g+\delta)+\left(1-e^{-\lambda t}\right) \frac{\alpha}{1-\alpha-\beta} \ln \left(s_{k}\right)+ \\
\left(1-e^{-\lambda t}\right) \frac{\beta}{1-\alpha-\beta} \ln \left(s_{h}\right)
\end{gathered}
$$

By considering that:

$$
\alpha_{1}=-\left(1-e^{-\gamma t}\right), \alpha_{2}=-\left(1-e^{-\lambda t}\right) \frac{\alpha+\beta}{1-\alpha-\beta}, \alpha_{3}=\left(1-e^{-\gamma t}\right) \frac{\alpha}{1-\alpha-\beta} \text { and } \alpha_{4}=\left(1-e^{-\gamma t}\right) \frac{\beta}{1-\alpha-\beta}
$$

The following test specification is obtained:

$$
\ln \left(\mathrm{y}_{\mathrm{t}}\right)-\ln \left(\mathrm{y}_{0}\right)=\alpha_{0}+\alpha_{1}\left(\mathrm{y}_{0}\right)+\alpha_{2} \ln (n+g+\delta)+\alpha_{3} \ln \left(s_{k}\right)+\alpha_{4} \ln \left(s_{h}\right)+\varepsilon_{\mathrm{t}}
$$

This specification only takes into account the determinants of economic growth within the steady state. We tried to extend this specification by considering, first, the nature of the time-series data and in addition to the basic model variables we take other variables which may influence the Moroccan aggregate production relying on the empirical studies conducted by (Barro \& others, 2003), (Bassanini \& Scarpetta, 2002), (Boccanfuso et al., 2009), (Khan, 2015).

In fact, in order to test the relationship between human capital and economic growth of Morocco we use the two specifications as follows:

$$
\begin{aligned}
& \ln \left(\mathrm{y}_{\mathrm{t}}\right)=\alpha_{0}+\alpha_{1} \ln \left(\mathrm{y}_{\mathrm{t}-5}\right)+\alpha_{2} \ln (\mathrm{n}+\mathrm{g}+\delta)+\alpha_{3} \ln \left(\mathrm{s}_{\mathrm{k}}\right)+\alpha_{4} \ln \left(\mathrm{s}_{\mathrm{h}}\right)+\alpha_{5} \ln (\text { Open })+\alpha_{6} \ln \left(\mathrm{R} \_ \text {agr }\right)+ \\
& \alpha_{7} \ln (\operatorname{Inf})+\varepsilon_{\mathrm{t}} \\
& \ln \left(\mathrm{y}_{\mathrm{t}}\right)-\ln \left(\mathrm{y}_{\mathrm{t}-1}\right)=\alpha_{0}+\alpha_{1} \Delta \ln \left(\mathrm{y}_{\mathrm{t}-5}\right)+\alpha_{2} \Delta \ln (\mathrm{n}+\mathrm{g}+\delta)+\alpha_{3} \Delta \ln \left(\mathrm{s}_{\mathrm{k}}\right)+\alpha_{4} \Delta \ln \left(\mathrm{s}_{\mathrm{h}}\right)+\alpha_{5} \Delta \ln (\text { Open })+ \\
& \alpha_{6} \Delta \ln \left(\mathrm{R}_{-} \text {agr }\right)+\alpha_{7} \Delta \ln (\mathrm{Inf})+\varepsilon_{\mathrm{t}}
\end{aligned}
$$

Where $y_{t}$ refers to the Gross Domestic Product by worker, $\mathrm{y}_{\mathrm{t}-5}$ represents the Gross Domestic Product by worker in date $\mathrm{t}-5^{3}, n_{t}$ is the growth rate of the active population, $g$ means the growth rate of technological progress and $\delta$ is the depreciation rate of human capital, $s_{k}$ represents the stock of physical capital, $s_{h}$ refers to the stock of human capital, OPEN is the trade openness index, $R_{-} a g r$ is the agriculture production index, Inf is the price increases indexand $\varepsilon_{\mathrm{t}}$ is the error term.

\subsection{Bayesian Model Averaging Method}

The empirical studies that examine determinants of economic growth suggest many potential explanatory variables, for example, (Durlauf et al., 2005) distinguish 43 models and 145 variables that determine economic growth. This context related to the lack of consensual theory that guides the choice of determinants of economic growth raise uncertainty about the true set of explanatory variables to use in model studied.

The BMA method overcome this problem in terms of uncertainty about the true set of explanatory variables by joining prior probabilities to alternative sets of explanatory variables and then update these probabilities using data collected. (Ciccone \& Jarocinski, 2008).

Like (Zeugner, 2011), if we suggest this equation of determinants of economic growth:

$$
\begin{gathered}
y=\alpha_{\gamma}+X_{\gamma} \beta_{\gamma}+\varepsilon \\
\varepsilon \rightarrow N\left(0, \sigma^{2} . I\right)
\end{gathered}
$$

Where $y$ referring to the dependent variable $\beta_{\gamma}$ is the vector of coefficients of explanatory variables $X_{\gamma}$ and $\varepsilon$ is the error term with variance $\sigma^{2}$.

If $\left\{X\right.$ \}has $\mathrm{K}$ potentials variables that means there are $2^{K}$ potentials models. These models are depended to $\beta_{\gamma}$ where $M_{\gamma}: \gamma=1,2, \ldots 2^{K}$.

as well, "the Bayesian approaches use Bayes theorem to convert the density of the data conditional on the model

\footnotetext{
${ }^{3}$ The introduction of parameter Gross Domestic Product by worker in date $t-5$ in specification is debatable. Some authors made estimations without introducing this variable. ( (Boccanfuso et al., 2009), (Ibourk \& Amaghouss, 2013), (Khan, 2015),)...).However, many authors introduced in their estimations (Mankiw et al., 1992), (Islam, 1995), (Berthélemy et al., 1997), (Ram, 2007)...). Following the previous authors, we decided to use this parameter in our estimation. In addition, we suppose that it reflect beginning of the government mandate in Morocco.
} 
(the marginal likelihood) into a posterior probability of the model conditional on the observed data" (Ciccone \& Jarocinski, 2008) as follows:

$$
\rho\left(M_{\gamma} / y, X\right)=\frac{\rho\left(y / M_{\gamma}, X\right) \rho\left(M_{\gamma}\right)}{\rho(y / X)}=\frac{\rho\left(y / M_{\gamma}, X\right) \rho\left(M_{\gamma}\right)}{\sum_{\gamma=1}^{2^{k}} \rho\left(y / M_{s}, X\right) \rho\left(M_{s}\right)}
$$

Where $\rho\left(M_{\gamma} / y, X\right)$ refers to posterior model probability which is proportional to marginal likelihood of the model $\rho\left(y / M_{\gamma}, X\right)$ and a prior model probability $\rho\left(M_{\gamma}\right), \rho(y / X)$ correspond to the integrated likelihood which is steady over all models. (Zeugner, 2011)

Knowing that $\int \rho\left(\mathrm{M}_{\gamma} / \mathrm{y}, \mathrm{X}\right) \mathrm{dM}_{\gamma}=1$, we get the function marginal likelihood of models:

$$
\rho(y / X)=\int \rho(y / X, X) \rho\left(M_{\gamma} / X\right) d M_{\gamma}
$$

Therefore, the model weighted posterior distribution of the coefficients of explanatory variable is as follows:

$$
\rho(\theta / y, X)=\sum_{\gamma=1}^{2^{k}} \rho\left(\theta / M_{\gamma}, y, X\right) \rho\left(y / M_{\gamma}, X\right)
$$

For our model the formula is:

$$
\rho\left(\beta_{\gamma} \neq 0 / \mathrm{y}, \mathrm{X}\right)=\sum_{\beta_{\gamma}} \rho\left(M_{\gamma} / y, X\right)
$$

This posterior probability measure the intensity of relation between the dependent variable and explanatory variables. However, in order to determine the posterior distribution of model coefficients we need to specify the prior on model parameters, which refer to weight of potential explanatory variable.

In order to determine the posterior distribution of model, we suppose like (Fernandez et al., 2001) and (Bodman et al., 2009)), the equal prior probabilities for all models or « unit information prior ».

Most authors used a common prior g specified by (Zellner, 1986) where:

$$
\beta_{\gamma} / g \sim \mathrm{N}\left(0, \sigma^{2}\left(\frac{1}{g} X_{\gamma}^{\prime} X_{\gamma}\right)^{-1}\right)
$$

\subsection{The Unit Root Testing}

The unit root testing allows both to detect the existence of trend and to determine the order of integration of series studied. These tests are important since they preclude the risk of spurious regression.

The literature review distinguishes several tests; the most widely used tests are the Dickey-Fuller augmented (ADF), Phillips-Perron (PP) and Kwiatkowski-Phillips-Schmidt-Shin (KPSS). We use the augmented Dickey-Fuller (ADF) and Phillips-Perron (PP) tests to detect the presence of unit roots.

The tests of ADF establish the alternative hypothesis $\left|\emptyset_{1}\right|<1$, which ascertain the estimation by the Method of Ordinary Least Square of the three equations:

$$
\begin{gathered}
\Delta x_{t}=\rho x_{t-1}-\sum_{j=2}^{\rho} \emptyset_{j} \Delta x_{t-j+1}+\varepsilon_{t} \\
\Delta x_{t}=\rho x_{t-1}-\sum_{j=2}^{\rho} \emptyset_{j} \Delta x_{t-j+1}+c+\varepsilon_{t} \\
\Delta x_{t}=\rho x_{t-1}-\sum_{j=2}^{\rho} \emptyset_{j} \Delta x_{t-j+1}+c+b_{t}+\varepsilon_{t}
\end{gathered}
$$

The estimation of the standard de viation coefficients of the models by the OLS provides $t_{\emptyset_{1}}$, which is analogous to the student statistic (coefficient on standard de viation) if $t_{\emptyset_{1}} \geq t_{\text {tabulated }}$, then we accept the hypothesis $H_{0}$; 
which implies the variable has unit root, so the process is not stationary. Besides, Phillips \&Perron unit root tests conducted from a regression similar to that of the Dickey and Fuller test.(Bourbonnais, 2005)

\subsection{Tests of Cointegration}

The theory of cointegration was initiated by (Granger, 1981), then later developed and popularized by (Engle \& Granger, 1987), (Johansen, 1988). The two-step (Engle \& Granger, 1987; Barro \& Lee, 2016) test only allows the identification of the number of cointegration relationships in the case of two variables. Johansen \& Juselius (1990) modified this test to study multiple variables.

They proposed two tests: the maximum eigenvalue test and the trace test.

$$
\begin{aligned}
& \lambda_{\text {trace }}(r)=-T \sum_{i=r+1}^{N} \ln \left(1-\widehat{\lambda_{l}}\right) \\
& \lambda_{\text {trace }}(r, r+1)=-T \ln \left(1-\widehat{\lambda_{l}}\right)
\end{aligned}
$$

Where $r$ is the number of cointegration vectors under the null hypothesis and $\lambda_{i}$ is the estimated value of the ith eigenvalue of the matrix. In the statistic $\lambda_{\text {trace }}$ we suppose the null hypothesis where the number of cointegration vectors is less than or equal to $r$ against the alternative hypothesis in which the number is greater than $r$ (for the test of the maximum eigenvalue, $\mathrm{H}_{0}: \mathrm{R}=\mathrm{r}$ against $\mathrm{H}_{1}: \mathrm{R}=\mathrm{r}+1$ ) (Vangu \& Boboy, 2013).

\subsection{Test of Causality}

The causality, in the sense of Granger (1969) between $X_{t}$ and $Y_{t}$ means that the prediction of $Y_{t}$ based on both the perception of the joint past of $\mathrm{X}_{\mathrm{t}}$ and $\mathrm{Y}_{\mathrm{t}}$ is better than the prediction based only on the past knowledge of $\mathrm{Y}_{\mathrm{t}}$.

The Granger causality test for the case of the two variables $Y_{t}$ and $X_{t}$ implies the estimation of the following autoregressive vector mołel (VAR):

$$
Y_{t}=\alpha_{1}+\sum_{j=1}^{n} \beta_{i} X_{t-1}+\sum_{i=1}^{n} \gamma_{j} Y_{t-j}+\varepsilon_{1 t} \text { and } X_{t}=\alpha_{1}+\sum_{i=1}^{n} \theta_{i} X_{t-1}+\sum_{i=1}^{n} \delta_{j} Y_{t-j}+\varepsilon_{2 t}
$$

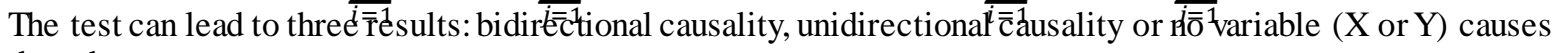
the other.

\section{Data, Empirical Results and Interpretations}

\subsection{Presentation of Data and Variables Selections}

In the context of the above empirical studies, the GDP per worker in constant 2005 US\$ is used as dependent variable. We have measured human capital by four proxies, of which two are quantitative and two qualitative, firstly the average years of schooling at the level of primary, secondary and higher education calculated by the methodology of the permanent inventory de veloped by (Nehru et al., 1995).

Secondly, the index of Morocco's life expectancy gap compared to developed countries, as measured by (Knowles \& Owen, 1995). We integrate the qualitative aspects of education and health by constructing two composite indicators of human capital using method of Principal Component Analysis (PCA). The choice of the methodology of Nehru et al., 1995 was because it takes into accounts the effects of repeating and dropping out of school.

The authors presume that children enter in school at the age of 6 , then, they get into the labor market at the age of 15 and leave it at the age of 64 , also in Moroccan primary education there is six grades $g$. Therefore, the equation for primary level is writing as follows:

$$
S_{P A}=\sum_{T-58}^{T-9} \sum_{g=1}^{6} E_{g, T-g-1}^{*}
$$

Where:

$$
E_{g t}^{*}=E_{g t}\left(1-r_{g t}-d_{g t}\right)
$$

$E_{g t}$ is the gross enrollment level of education adjusted by repetition rates $\left(r_{g t}\right)$ and drop-out rate $\left(d_{g t}\right)$. The same approach is used to calculate secondary and tertiary education.

To measure the health dimension, Authors used several indicators: Food intake, life expectancy, infant mortality rate and public health expenditure. Nevertheless, in most empirical studies, life expectancy is used as a health proxy, see ( (Nadiri, 1972), (Hicks, 1980), (Anand \& Ravallion, 1993), (Knowles \& Owen, 1995), (Bloom et al., 2004)).

We suggest approximating the health dimension by the following index: 


$$
\text { Health case indicator }=-\ln \left(80-\text { lifeExp }_{t}\right)
$$

This indicator takes into account the "shortfall" in terms of years of life to reach the level of the most developed countries that corresponds to 80 years.

Finally, to capture the qualitative aspects of human capital, we have extended the methodology developed by (Boccanfuso et al., 2009) who used the techniques of multivariate analysis to construct synthetic indicators of the quality of the education system ${ }^{4}$.

According to Berthélemy et al. (1997) and Abdouni \& Hanchane (2008), the effects of human capital in economic growth depend to the public policy of country particularly the policy of openness and economic stability. We consider a composite index of openness policy ${ }^{5}$ and we use cereal yield (kg per hectare) and the rate of inflation as proxies of economic stability in Morocco ${ }^{6}$.

\subsection{Results of Unit Root Tests and Johansen Co-integration Test}

As can be seen from the Table 1, the results of unit root tests leads to the conclusion that only the variables $\Delta \mathrm{lGDP}$, LinvGDP, $\mathrm{L}(\mathrm{n}+\mathrm{g}+\S)$, LGDP(t-5), lmyscho, Llifeexpind, inf et Lr-agricul are stationary and that the variables eduqualind, healqualind and openness are non-stationary in level but stationary in first difference.

The results show the possibility of a cointegration relationship between the variables: the growth rate of GDP per worker, the rate of investment, the growth of active population, the GDP in date $(t-5)$, the average years of education of the labor force, life expectancy, the indicator of agriculture and the rate of inflation.

Before starting the cointegration test, we determine the number of delays of our VAR model based on the information criteria of (Akaike, 1974), (Schwarz \& others, 1978)and (Hannan \& Quinn, 1979). As result, we identify one number of retard in the first specification and Zero retard in the second specification. (See Table 2and Table 3)

As in the Table 4, the results show that there are four linear co-integration relationships in the (Mankiw et al., 1992) specification, which shows the existence of a long-run relationship between GDP per worker and human capital approximated by the average years of study. However, we found that there is no linear co-integration relationship when we integrate the health dimension, ((Ram, 2007) specification) and the results show three linear co-integration relationships when we has introduced the qualitative dimension of human capital resulting from (PCA), ((Boccanfuso et al., 2009)specification).

As in the Table 5, the results show that there are more than five linear co-integration relationships, which shows the existence of a long-run relationship between the growth of the GDP per worker and human capital.

\footnotetext{
${ }^{4}$ Boccanfuso et al., (2009) consider only the qualitative aspects of education; we propose to introduce the qualitative aspects of health. We take into account the following variables: life expectancy, birth rate, gross (per 1,000 persons), infant mortality rate (per 1,000 live births), maternal mortality rate (per 1,000 live births), the number of physicians per capita, total health expenditure (\% of GDP) and student-teacher ratio in primary, secondary and tertiary education.

${ }^{5}$ The composite index of openness results in applying PCA to these variables: Exports and imports of goods and services, personal remittances received, international tourism receipts, total foreign direct investment (FDI) inflows, net official development assistance received, investment in telecoms with private participation and external debt. All these variables reported as percentage of GDP and we added insurance and financial services as a percentage of commercial service exports.

${ }^{6}$ The choice of cereal yield (kg per hectare) as indicator of economic stability due to vulnerability of agricultural production to climatic conditions (Mansouri, 2009).
} 
Table 1. Results of Augmented Dickey Fuller (ADF) and Phillips and Perron tests for unit root

\begin{tabular}{|c|c|c|c|c|c|c|c|c|c|c|c|c|}
\hline \multirow[t]{3}{*}{ Variables } & \multicolumn{6}{|c|}{ Augmented Dickey Fuller (ADF) test } & \multicolumn{6}{|c|}{ Phillips and Perron test } \\
\hline & \multicolumn{2}{|c|}{$\begin{array}{l}\text { Test without } \\
\text { both constant } \\
\text { and trend }\end{array}$} & \multicolumn{2}{|c|}{$\begin{array}{l}\text { Test with } \\
\text { constant }\end{array}$} & \multicolumn{2}{|c|}{$\begin{array}{l}\text { Test with both } \\
\text { constant and } \\
\text { trend }\end{array}$} & \multicolumn{2}{|c|}{$\begin{array}{l}\text { Test without } \\
\text { both constant } \\
\text { and trend }\end{array}$} & \multicolumn{2}{|c|}{$\begin{array}{l}\text { Test with } \\
\text { constant }\end{array}$} & \multicolumn{2}{|c|}{$\begin{array}{l}\text { Test with both } \\
\text { constant and } \\
\text { trend }\end{array}$} \\
\hline & T-stat & Pval & T-stat & Pval & T-stat & Pval & T-stat & Pval & T-stat & $\begin{array}{l}\mathrm{P} \\
\text { val }\end{array}$ & T- stat & P val \\
\hline$\triangle \mathrm{lGDP}$ & -7.53 & 0.00 & -10 & 0.00 & -9.92 & 0.00 & -7.53 & 0.00 & -10 & 0.00 & -9.92 & 0.00 \\
\hline LinvGDP & -1.89 & 0.06 & $\begin{array}{c}- \\
7.32\end{array}$ & 0.00 & -7.82 & 0.00 & -1.89 & 0.06 & $\begin{array}{c}- \\
7.32\end{array}$ & 0.00 & -7.82 & 0.00 \\
\hline $\mathrm{L}(\mathrm{n}+\mathrm{g}+\S)$ & -0.26 & 0.78 & $\begin{array}{c}- \\
3.53\end{array}$ & 0.01 & -4.07 & 0.01 & -0.26 & 0.78 & 3.53 & 0.01 & -4.07 & 0.01 \\
\hline $\operatorname{LGDP}(\mathrm{t}-5)$ & 3.35 & 0.01 & $\begin{array}{c}- \\
1.39\end{array}$ & 0.59 & -3.23 & 0.08 & 3.35 & 0.01 & $\begin{array}{c}- \\
1.39\end{array}$ & 0.59 & -3.23 & 0.08 \\
\hline Lmyscho & -2.36 & 0.02 & 4.79 & 0.01 & -4.4 & 0.01 & -2.36 & 0.02 & 4.79 & 0.01 & -4.4 & 0.01 \\
\hline Llifeexpind & -11.98 & 0.00 & 5.66 & 1.00 & -2.11 & 0.54 & -11.98 & 0.00 & 5.66 & 1.00 & -2.11 & 0.54 \\
\hline eduqualind & -0.79 & 0.43 & $0 . \overline{-}$ & 0.83 & -3.5 & 0.04 & -0.79 & 0.00 & $0 . \overline{-}$ & 0.83 & -3.5 & 0.04 \\
\hline$\Delta$ eduqualind & -6.64 & 0.00 & -6.8 & 0.00 & -6.74 & 0.00 & -6.63 & 0.72 & -6.8 & 0.00 & -6.73 & 0.00 \\
\hline healqualind & -1.17 & 0.25 & $\overline{-}$ & 0.69 & -2.67 & 0.25 & -1.17 & 0.25 & $\overline{-}$ & 0.69 & -2.67 & 0.25 \\
\hline$\Delta$ healqualind & -9.00 & 0.00 & 9.54 & 0.00 & -9.5 & 0.00 & -9.00 & 0.00 & 9.54 & 0.00 & -9.5 & 0.00 \\
\hline openness & -1.77 & 0.08 & $\begin{array}{c}- \\
1.74\end{array}$ & 0.41 & -2.43 & 0.36 & -1.77 & 0.08 & $\begin{array}{c}- \\
1.74\end{array}$ & 0.41 & -2.43 & 0.36 \\
\hline$\Delta$ openness & -8.53 & 0.00 & -8.5 & 0.00 & -8.45 & 0.00 & -8.53 & 0.00 & -8.5 & 0.00 & -8.45 & 0.00 \\
\hline Inf & -2.02 & 0.05 & $\begin{array}{c}- \\
3.00\end{array}$ & 0.04 & -3.46 & 0.04 & -2.02 & 0.05 & 3.00 & 0.04 & -3.46 & 0.04 \\
\hline Lr-agricul & -0.17 & 0.87 & $\begin{array}{c}- \\
7.06 \\
\end{array}$ & 0.08 & -7.77 & 0.00 & -0.17 & 0.87 & $\begin{array}{c}- \\
7.06 \\
\end{array}$ & 0.08 & -7.77 & 0.00 \\
\hline
\end{tabular}

Table 2. VAR lag order selection criteria (Dependent variable LGDP)

\begin{tabular}{|c|c|c|c|c|c|c|c|c|c|}
\hline Specifications & \multicolumn{3}{|c|}{ (Mankiw et al., 1992) } & \multicolumn{3}{|c|}{ (Ram, 2007) } & \multicolumn{3}{|c|}{ (Boccanfuso et al., 2009) } \\
\hline Number de retard & AIC & HQIC & SBIC & AIC & HQIC & SBIC & AIC & HQIC & SBIC \\
\hline 0 & -4.95 & -4.84 & -4.67 & -5.40 & -5.29 & -5.11 & -4.43 & $-4.31 *$ & $-4.11 *$ \\
\hline 1 & -6.31 & -6.19 & $-5.98 *$ & -6.31 & -5.99 & $-5.99 *$ & -6.27 & -6.13 & -5.91 \\
\hline 2 & -6.29 & -6.15 & -5.92 & -6.28 & -5.91 & -5.92 & -6.31 & -6.17 & -5.83 \\
\hline 3 & -6.26 & -6.11 & -5.86 & -6.26 & -5.86 & -5.86 & -6.27 & -6.11 & -5.78 \\
\hline
\end{tabular}

Table 3. VAR lag order selection criteria(Dependent variable DlGDP)

\begin{tabular}{|c|c|c|c|c|c|c|c|c|c|}
\hline Specifications & \multicolumn{3}{|c|}{ (Mankiw et al., 1992) } & \multicolumn{3}{|c|}{ (Ram, 2007) } & \multicolumn{3}{|c|}{ (Boccanfuso et al., 2009) } \\
\hline Number de retard & AIC & HQIC & SBIC & $\overline{\mathrm{AIC}}$ & HQIC & SBIC & $\overline{\mathrm{AIC}}$ & HQIC & SBIC \\
\hline 0 & $-5.17^{*}$ & $-5.07 *$ & $-4.89 *$ & -5.17 & $-5.07 *$ & $-4.89 *$ & -5.22 & $-5.10 *$ & $-4.90 *$ \\
\hline 1 & -5.14 & -5.03 & -4.82 & -5.15 & -5.03 & -4.83 & -5.21 & -5.08 & -4.85 \\
\hline 2 & -5.10 & -4.97 & -4.74 & -5.10 & -4.97 & -4.74 & -5.17 & -5.02 & -4.77 \\
\hline 3 & -5.09 & -4.96 & -4.71 & -5.10 & -4.96 & -4.71 & -5.10 & -5.02 & -4.74 \\
\hline
\end{tabular}

Table 4. Results of Unrestricted co-integration rank test: (Dependent variable LGDP)

\begin{tabular}{|c|c|c|c|c|c|c|c|}
\hline \multirow[b]{2}{*}{$H_{0}$} & \multirow{2}{*}{$\begin{array}{c}\text { Specifications } \\
H_{1}\end{array}$} & \multicolumn{2}{|c|}{ (Mankiw et al., 1992) } & \multicolumn{2}{|c|}{ (Ram, 2007) } & \multicolumn{2}{|c|}{ (Boccanfuso et al., 2009) } \\
\hline & & Rank test & $5 \%$ crit. val. & Rank test & $5 \%$ crit. val. & Rank test & $5 \%$ crit. val. \\
\hline$r=0$ & $r \geq 1$ & 446.15 & 156.00 & 359.76 & 124.24 & 465.21 & 156.00 \\
\hline$r \leq 1$ & $r \geq 2$ & 303.35 & 124.24 & 221.67 & 94.15 & 323.36 & 124.24 \\
\hline$r \leq 2$ & $r \geq 3$ & 210.36 & 94.15 & 142.45 & 68.52 & 239.55 & 94.15 \\
\hline$r \leq 3$ & $r \geq 4$ & 151.06 & 68.15 & 90.10 & 47.21 & 172.21 & 68.15 \\
\hline$r \leq 4$ & $r \geq 5$ & 100.45 & 47.21 & 43.60 & 29.68 & 117.59 & 47.21 \\
\hline$r \leq 5$ & $r \geq 6$ & 55.41 & 29.68 & $11.01 *$ & 15.41 & 68.74 & 29.68 \\
\hline$r \leq 6$ & $r \geq 7$ & 18.69 & 15.41 & 4.04 & 3.76 & 34.01 & 15.41 \\
\hline$r \leq 7$ & $r \geq 8$ & $1.44 *$ & 3.76 & & & $1.94 *$ & 3.76 \\
\hline
\end{tabular}


Table 5. Results of Unrestricted co-integration rank test: (Dependent variable DIGDP)

\begin{tabular}{|c|c|c|c|c|c|c|c|}
\hline \multirow[b]{2}{*}{$H_{0}$} & \multirow{2}{*}{$\frac{\text { Specifications }}{H_{1}}$} & \multicolumn{2}{|c|}{ (Mankiw et al., 1992) } & \multicolumn{2}{|c|}{ (Ram, 2007) } & \multicolumn{2}{|c|}{ (Boccanfuso et al., 2009) } \\
\hline & & Rank test & $5 \%$ crit. val. & Rank test & $5 \%$ crit. val. & Rank test & $5 \%$ crit. val. \\
\hline$r=0$ & $r \geq 1$ & 323.65 & 156.00 & 353.97 & 156.00 & 260.80 & 192.89 \\
\hline$r \leq 1$ & $r \geq 2$ & 208.13 & 124.24 & 239.69 & 124.24 & 191.36 & 156.00 \\
\hline$r \leq 2$ & $r \geq 3$ & 136.20 & 94.15 & 173.11 & 94.15 & 127.77 & 124.24 \\
\hline$r \leq 3$ & $r \geq 4$ & 88.15 & 68.52 & 116.54 & 68.52 & $77.47 *$ & 94.15 \\
\hline$r \leq 4$ & $r \geq 5$ & $45.20 *$ & 47.21 & 76.32 & 47.21 & 49.76 & 68.52 \\
\hline$r \leq 5$ & $r \geq 6$ & 21.51 & 29.68 & 47.15 & 29.68 & 30.27 & 47.21 \\
\hline$r \leq 6$ & $r \geq 7$ & 7.54 & 15.41 & 20.64 & 15.41 & 16.61 & 29.68 \\
\hline$r \leq 7$ & $r \geq 8$ & 2.15 & 3.76 & 5.87 & 3.76 & 0.34 & 15.41 \\
\hline
\end{tabular}

5.3 Regression Analysis

As seen in Table 6, we investigates the determinants of LGDP, If we refer to the criteria of (Raftery, 1995) which suggests that the posterior probabilities should be higher than 0,5 . We distinguish five variables that affect significantly GDP per worker where three are proxies of human capital: The average years of total schooling that affects positively and significantly GDP per worker with the probability of 0.9976 . Also, these results show that the life expectancy index affects positively and significantly GDP per worker with the probability of 0.6312 and the quality index of health resulting from the PCA method affects positively and significantly the growth of GDP per worker with the probability of 0.8496 . However, the quality index of education resulting from the PCA method affects negatively and not significantly GDP per worker.

These results confirm that the economic growth is affected by degree of growth of human capital measured by growth of average years of total schooling and health indicator used.

These results could be explained in two ways: either the Moroccan economy is characterized by the low level of quality of education, as shown by (Pritchett, 2001) or the stock of human capital is allocated in low productivity sectors (Murphy et al., 1991).

In addition, we found that the indicator of openness resulting from the PCA method and the agricultural production index has positive and significant impact on GDP per worker respectively with the probability of 0.8338 and 0.9864 .

These results could be explained by the fact that the policy of openness made by Morocco promoted the economic growth by insuring transfer of qualifications and new technologies. However, the Moroccan authorities need to make additional efforts to obtain much opportunities related to this policy. In addition, the agricultural production index affects positively and significantly the GDP per worker that confirms the dependence of Moroccan economic growth on agricultural production: The agriculture sector contributes to more than $14 \%$ of GDP and creates employment of more than $75 \%$ of population in rural areas.

As seen in Table 7, we investigates the determinants of the growth of GDP per worker, we found that only the growth of physical capital and growth of active that affects significantly the growth of GDP per worker. As for the four proxies of human capital, they affects positively but not significantly the economic growth of Morocco.

As in the Table 8 and the Table 9, the results of Granger causality test show first that only the indicator of quality of health that cause the GDP per worker. Secondly, these results show that the average years of total schooling and the indicator of quality of education cause the growth of GDP per worker and the growth of GDP cause the growth of the quality index of health. 
Table 6. Results of Bayesian Model Averaging method data from 1965 to 2015: (Dependent variable LGDP)

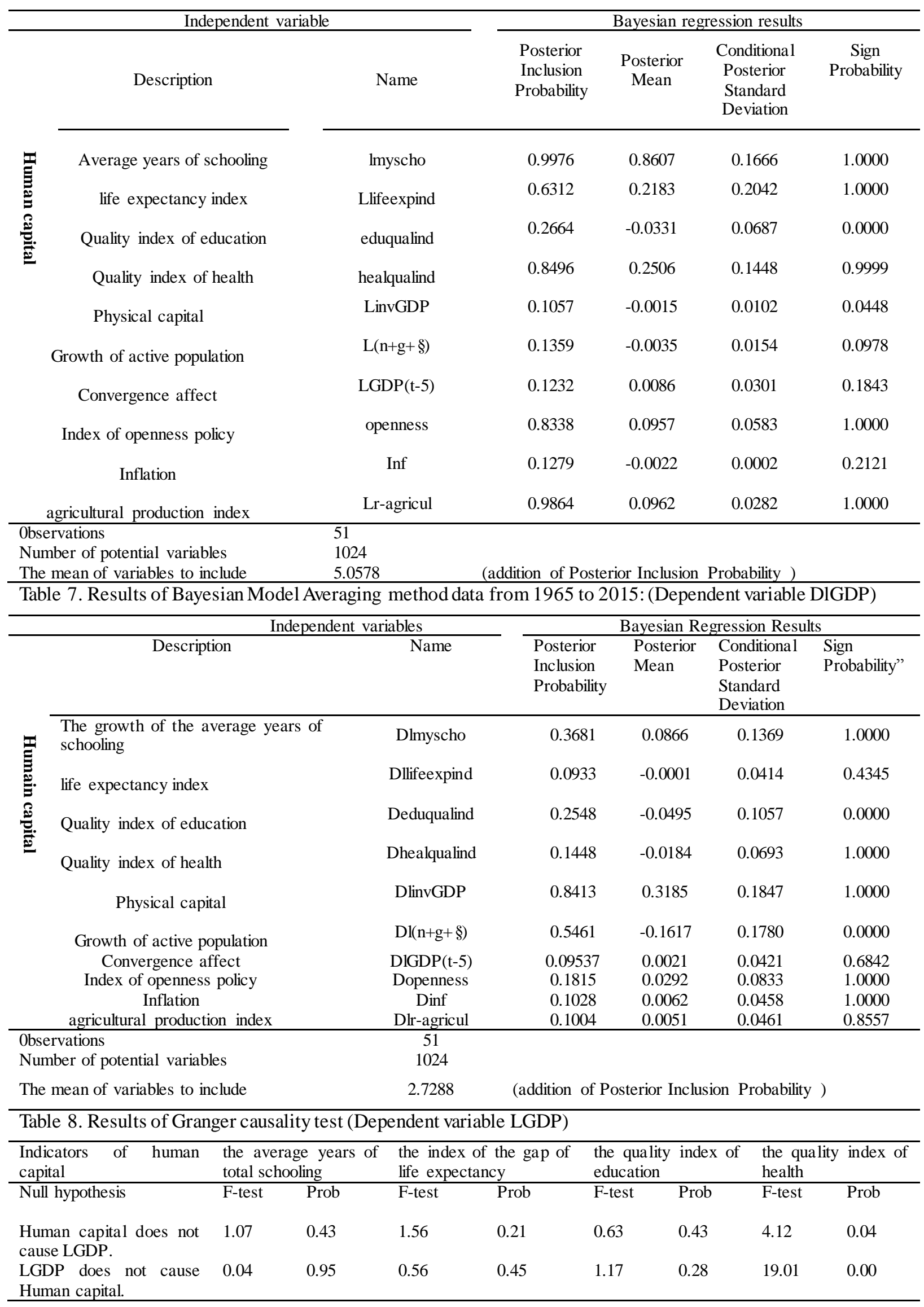


Table 6. Results of Granger causality test (Dependent variable DIGDP)

\begin{tabular}{|c|c|c|c|c|c|c|c|c|}
\hline $\begin{array}{l}\text { Indicators of human } \\
\text { capital }\end{array}$ & \multicolumn{2}{|c|}{$\begin{array}{l}\text { the average years of } \\
\text { total schooling }\end{array}$} & \multicolumn{2}{|c|}{$\begin{array}{l}\text { the index of the gap in } \\
\text { life expectancy }\end{array}$} & $\begin{array}{l}\text { the qualit } \\
\text { education } \\
\text { F-test }\end{array}$ & \multirow{2}{*}{$\begin{array}{l}\text { index o } \\
\text { Prob }\end{array}$} & \multirow{2}{*}{$\begin{array}{l}\text { the qua } \\
\text { health } \\
\text { F-test }\end{array}$} & \multirow{2}{*}{$\begin{array}{l}\text { index of } \\
\text { Prob }\end{array}$} \\
\hline Null hypothesis & F-test & Prob & F-test & Prob & & & & \\
\hline $\begin{array}{l}\text { Human capital does not } \\
\text { cause DlGDP. }\end{array}$ & 11.15 & 0.001 & 1.55 & 0.69 & 6.23 & 0.01 & 1.59 & 0.21 \\
\hline $\begin{array}{l}\text { DlGDP does not cause } \\
\text { Human capital. }\end{array}$ & 0.73 & 0.79 & 0.16 & 0.69 & 0.24 & 0.62 & 6.1 & 0.08 \\
\hline
\end{tabular}

\section{Conclusion}

Human capital is at the heart of empirical works that explain the determinants of economic growth. Although, many authors argue that human capital may affect positively and significantly the economic growth several empirical studies obtained controversial results.

This paper investigates the relationship between human capital and economic growth in Morocco during the period from 1965 to 2015. In order to test this relationship, we firstly use the Johansen multivariate cointegration test and the Granger causality test. Secondly, we use the method of the Bayesian Model Averaging which takes into consideration the uncertainty related to the specification of the model studied. In order to measure human capital, we have used four proxies of human capital: first, the average years of total schooling, second the index of the gap in life expectancy between Morocco and developed countries and third we integrate the qualitative aspects of education and health by constructing two composite indicator of human capital using method of Principal Component Analysis (PCA).

The main results confirm that in the specification of determinants of GDP per worker the average years of total schooling, the life expectancy index and the indicator of quality of health affect positively and significantly level of GDP per worker. However, in the specification of determinants of the growth of the GDP per worker, we found there is no proxy of human capital that affects significantly the growth of the GDP per worker.

In addition, the results of Granger causality test show that only the indicator of quality of health that cause the GDP per worker. As well, these results show that the average years of total schooling and the indicator of quality of education cause the growth of GDP per worker. We suggest that the Moroccan authorities should make additional efforts to raise the level of quality of human capital especially in the health sector and increase the productivity of both public and private investment.

\section{References}

Abdouni, A., \& Hanchane,S.(2008). Ala recherche des liens hétérogènes entre l'ouverture, le capital humain et la croissance économique dans les pays en voie de développement: un examen à l'aide des données de panel. Critique économique: La revue des économistes critiques" IMIST, service de coopération et d'action culturelle de l'ambassade de france au maroc, 9, 99-130.

Aghion, P., \& Howitt, P. (1992). Un modèle de croissance par destruction créatrice. Economica, Paris, 177-212.

Aghion, P., \& Howitt, P. (1998). Endogeneous growth theory. Cambridge: MIT Press.

Akaike, H. (1974). A new look at the statistical model identification. IEEE transactions on automatic control, 19 , 716-723. https://doi.org/10.1109/TAC.1974.1100705

Altinok, N., Diebolt, C., \& Demeulemeester, J. L. (2014). A new international database on education quality: 1965--2010. Applied Economics, 46, 1212-1247. https://doi.org/10.1080/00036846.2013.868592

Altinok, N., \& Murseli, H. (2007). International database on human capital quality. Economics Letters, 96, 237-244. https://doi.org/10.1016/j.econlet.2007.01.009.

Anand, S., \& Ravallion, M. (1993). Human de velopment in poor countries: on the role of private incomes and public services. The Journal of Economic Perspectives, 7, 133-150. https://doi.org/10.1257/jep.7.1.133

BAD, B. A. D. D. (2013). Programme d'appui a la reforme de la couverture medicale - phase 3. [Online] Departement OSHD Available at: https://www.afdb.org [Accessed 15 Decembre 2016].

Barro, R. J. (1991). Economic growth in a cross section of countries. The quarterly journal of economics, 106, 407-443. https://doi.org/10.2307/2937943

Barro, R. J., \& Lee, J. W. (1994). Sources of economic growth. In Carnegie-Rochester conference series on public policy., 1994. https://doi.org/10.1016/0167-2231(94)90002-7

Barro, R. J., \& Lee, J. W. (2001). International data on educational attainment: updates and implications. oxford 
Economic papers, 53, 541-563. https://doi.org/10.1093/oep/53.3.541

Barro, R. J., \& Lee, J. W. (2016). Educational Attainment Dataset. [Online] Available at: www.barrolee.com [Accessed 25 December 2016].

Barro, R. J. et al. (2003). Determinants of economic growth in a panel of countries. Annals of economics and finance, 4, 231-274.

Bassanini, A., \& Scarpetta, S. (2002). Does human capital matter for growth in OECD countries? A pooled mean-group approach. Economics letters, 74, 399-405. https://doi.org/10.1016/S0165-1765(01)00569-9.

Becker, G. S. (1962). Investment in human capital: A theoretical analysis. Journal of political economy, 70, 9-49. https://doi.org/10.1086/258724

Benhabib, J., \& Spiegel, M. M. (1994). The role of human capital in economic development evidence from aggregate cross-country data. Journal of Monetary economics, 34, 143-173. https://doi.org/10.1016/0304-3932(94)90047-7

Berthélemy, J. C., Dessus, S., \& Varoudakis, A. (1997). Capital humain et croissance: le rôle du régime commercial. Revue économique, 419-428.

Bloom, D. E., Canning, D., \& Sevilla, J. (2004). The effect of health on economic growth: a production function approach. World development, 32, 1-13. https://doi.org/10.1016/j.worlddev.2003.07.002

Bloom, D. E., \& Mahal, A. S. (1995). Does the AIDS epidemic really threaten economic growth? Tech. rep. National bureau of economic research.

Boccanfuso, D., Savard, L., \& Savy, B. (2009). Capital humain et croissance: évidences sur données de pays africains. Cahier de recherche/Working Paper, 9, 15.

Bodman, P., Heaton, K. A., \& Hodge, A., et al. (2009). Fiscal decentralisation and economic growth: A Bayesian model averaging approach. School of Economics, University of Queensland, Australia. .

Bouayad, A. (1994). Capital humain et croissance des pays en développement le cas du Maroc. Thèse de doctorat en sciences économiques. Toulouse, FRANCE: Université Toulouse.

Bouoiyour, J. (2000). Relation éducation croissance économique au Maroc Long terme ou court terme. Tech.rep. University Library of Munich, Germany.

Bouoiyour, J., \& Bennaghmouch, S. (2002). Capital humain et croissance économique au Maroc. Tech. rep. University Library of Munich, Germany.

Bouoiyour, J., \& Hanchane, H. et al. (2009). Investissements directs étrangers et productivité. Revue économique, 60, 109-131. https://doi.org/10.3917/reco.601.0109

Bourbonnais, R. (2005). Econométrie. DUNOD, (6éme éditions).

Caselli, F., Esquivel, G., \& Lefort, F. (1996). Reopening the convergence debate: a new look at cross-country growth empirics. Journal of economic growth, 1, 363-389. https://doi.org/10.1007/BF00141044

CESE, C. E. S. E. E. (2013). Les soins de santé de base Vers un accès équitable et généralisé. [Online] RABAT, Maroc: Imprimerie SIPAMA SARL Available at:

http://www.ces.ma/Documents/PDF/Rapport\%20SSB\%20VF.pdf [Accessed 21 Juin 2016]

Ciccone, A., \& Jarocinski, M. (2008). Determinants of Economic Growth Will Data Tell? European Central Bank Working Paper Series No 852.

De la Fuente, Á., \& Doménech, R. (2002). Educational Attainment in the OECD, 1960-95. CEPR Discussion Paper No. 3390. SSRN: https://ssrn.com/abstract=317689

Denison, E. F. (1962). The Sources of Economic Growth in the US and the Alternatives before Us. Committee for Economic Development.

Dessus, S. (2000). Capital humain et croissance: le rôle retrouvé du système éducatif. économie publique, 2(6), 95-115.

Durlauf, S. N., Johnson, P. A., \& Temple, J. R. W. (2005). Growth econometrics. Handbook of economic growth, 1, 555-677. https://doi.org/10.1016/S1574-0684(05)01008-7

Engle, R. F., \& Granger, C. W. J. (1987). Co-integration and error correction: representation, estimation, and testing. Econometrica: journal of the Econometric Society, 251-276. https://doi.org/10.2307/1913236 
Fall, A., \& Thiaw, K. (2012). Productivité des Dépenses Publiques et Croissance Economique dans l'UEMOA:Une Analyse Bayésienne sur Données de Panel. DPEE Senegal.

Fernandez, C., Ley, E., \& Steel, M. F. J. (2001). Benchmark priors for Bayesian model averaging. Journal of Econometrics, 100, 381-427. https://doi.org/10.1016/S0304-4076(00)00076-2

Fetahi-Vehapi, M., Sadiku, L., \& Petkovski, M. (2015). Empirical Analysis of the Effects of Trade Openness on Economic Growth: An Evidence for South East European Countries. Procedia Economics and Finance, 19, 17-26. https://doi.org/10.1016/S2212-5671(15)00004-0

Granger, C. W. J. (1969). Investigating causal relations by econometric models and cross-spectral methods. Econometrica: Journal of the Econometric Society, 424-438. https://doi.org/10.2307/1912791

Granger, C. W. J. (1981). Some properties of time series data and their use in econometric model specification. Journal of econometrics, 16, 121-130. https://doi.org/10.1016/0304-4076(81)90079-8.

Hannan, E. J., \& Quinn, B. G. (1979). The determination of the order of an autoregression. Journal of the Royal Statistical Society. Series B (Methodological), 190-195.

Hanushek, E. A., \& Kimko, D. D. (2000). Schooling, labor-force quality, and the growth of nations. American economic review, 1184-1208. https://doi.org/10.1257/aer.90.5.1184

Hanushek, E. A., \& Woessmann, L. (2012). Do better schools lead to more growth? Cognitive skills, economic outcomes, and causation. Journal of economic growth, 17, 267-321. https://doi.org/10.1007/s10887-012-9081-x

Hicks, N. L. (1980). Is there a tradeoff between growth and basic needs? Finance and Development, 17, 17.

Ibourk, A., \& Amaghouss, J. (2013). Education and Economic Growth in the MENA Region: Some New Evidence. Journal of Economics and Sustainable Development.

Islam, N. (1995). Growth empirics: a panel data approach. The Quarterly Journal of Economics, 110, 1127-1170. https://doi.org/10.2307/2946651

Johansen, S. (1988). Statistical analysis of cointegration vectors. Journal of economic dynamics and control, 12, 231-254. https://doi.org/10.1016/0165-1889(88)90041-3

Johansen, S., \& Juselius, K. (1990). Maximum likelihood estimation and inference on cointegration-with applications to the demand for money. Oxford Bulletin of Economics and statistics, 52, 169-210. https://doi.org/10.1111/j.1468-0084.1990.mp52002003.x

Khan, M. K. (2015). Contribution of female human capital in economic growth: an empirical analysis of Pakistan (1972-2012). Springer Science and Business Media, 50, 709. https://doi.org/10.1007/s11135-015-0172-6

Knowles, S., \& Owen, P. D. (1995). Health capital and cross-country variation in income per capita in the Mankiw-Romer-Weil model. Economics letters, 48, 99-106. https://doi.org/10.1016/0165-1765(94)00577-O

Koukpo, M. T. (2005). Déterminants des investissements directs étrangers dans les pays de l'UEMOA. African Institute for Economic Development and Planning (IDEP), Dakar.

Kruger, A. B., \& Lindahl, M. (2001). Education for growth: Why and for whom. Journal of Economic Literature, 39, 1101-1136. https://doi.org/10.1257/jel.39.4.1101

Leon-Gonzalez, R., \& Vinayagathasan, T. (2015). Robust determinants of growth in Asian de veloping economies: A Bayesian panel data model averaging approach. Journal of Asian Economics, 36, 34-46. https://doi.org/10.1016/j.asieco.2014.12.001

Lucas, R. E. (1988). On the mechanics of economic development. Journal of monetary economics, 22, 3-42. https://doi.org/10.1016/0304-3932(88)90168-7

Mankiw, N. G., Romer, D., \& Weil, D. N. (1992). A contribution to the empirics of economic growth. The quarterly journal of economics, 107, 407-437. http://dx.doi.org/10.2307/2118477

Mansouri, B. (2009). Effets des IDE et de l'ouverture commerciale sur la croissance economique au Maroc. Centre de conferences des Nations Unies, Addis-Abeba, Ethiopie.

Mbulawa, S. (2015). Determinants of Economic Growth in Southern Africa Development Community: The Role of Institutions. Applied Economics and Finance, 2, 91-102. https://doi.org/10.11114/aef.v2i2.782

Mincer, J. (1958). Investment in human capital and personal income distribution. Journal of political economy, 


\section{6, 281-302. https://doi.org/10.1086/258055}

Mincer, J. (1974). Schooling, Experience, and Earnings. Human Behavior \& Social Institutions No. 2.

Murphy, K. M., Shleifer, A., \& Vishny, R. W. (1991). The allocation of talent: Implications for growth. The quarterly journal of economics, 106, 503-530. https://doi.org/10.2307/2937945

Nadiri, M. I. (1972). International studies of factor inputs and total factor productivity: A brief survey. Review of Income and Wealth, 18, 129-154. https://doi.org/10.1111/j.1475-4991.1972.tb00855.x

Nehru, V., Swanson, E., \& Dubey, A. (1995). A new database on human capital stock in developing and industrial countries: Sources, methodology, and results. Journal of development Economics, 46, 379-401. https://doi.org/10.1016/0304-3878(94)00054-G

Nelson, R. R., \& Phelps, E. S. (1966). Investment in humans, technological diffusion, and economic growth. The American economic review, 56, 69-75.

Noorbakhsh, F., Paloni, A., \& Youssef, A. (2001). Human capital and FDI inflows to developing countries: New empirical evidence. World development, 29, 1593-1610. https://doi.org/10.1016/S0305-750X(01)00054-7

Pritchett, L. (2001). Where has all the education gone? The world bank economic review, 15, 367-391. https://doi.org/10.1093/wber/15.3.367

Raftery, A. E. (1995). Bayesian model selection in social research. Sociological methodology, 111-163. https://doi.org/10.2307/271063

Ram, R. (2007). IQ and economic growth: Further augmentation of Mankiw--Romer--Weil model. Economics Letters, 94, 7-11. https://doi.org/10.1016/j.econlet.2006.05.005

Romer, P. M. (1986). Increasing returns and long-run growth. Journal of political economy, 94, 1002-1037. https://doi.org/10.1086/261420

Romer, P. M. (1989). What determines the rate of growth and technological change? World Bank Publications.

Romer, P. M. (1990). Endogenous technological change. Journal of political Economy, 98, S71--S102. https://doi.org/10.1086/261725

Sbaouelgi, J. (2015). L'impact de l'Enseignement Supérieur sur la Croissance Economique LÍmpact de lÉnseignement Supérieur sur la Croissance Economique Cas de la Tunisie, le Maroc et la Corée du Sud. Tech.rep. University Library of Munich, Germany.

Schoellman, T. (2011). Education quality and development accounting. The Review of Economic Studies, 79, 388-417. https://doi.org/10.1093/restud/rdr025

Schultz, T. W. (1961). Investment in human capital. The American economic review, 51, 1-17.

Schwarz, G. et al. (1978). Estimating the dimension of a model. The annals of statistics, 6, 461-464. https://doi.org/10.1214/aos/1176344136

Smith, A. (1795). history of astronomy, in essays on philosophical subjects. londres,Cadell and Davis, cited by Amartya S (2000).

Sunde, U., \& Vischer, T. (2011). Human capital and growth: Specification matters. Tech.rep. IZA Discussion Paper No. 5991, Bonn Germany.

UNESCO, O.d.N.u.p.l.1.s.e.l.c. 2016. institut de statistique de l'unesco. [Online] Available at: uis.unesco.org/fr [Accessed 20 November 2016].

Vangu, T. K., \& Boboy, T. Y. (2013). Cointégration et modéle à correction d'erreur. Cours. Lareq.

Zellner, A. (1986). On assessing prior distributions and Bayesian regression analysis with g-prior distributions. Bayesian inference and decision techniques: Essays in Honor of Bruno De Finetti, 6, 233-243.

Zeugner, S. (2011). Bayesian model averaging with BMS. Tutorial to the R-package BMS 1e30.

\section{Copyrights}

Copyright for this article is retained by the author(s), with first publication rights granted to the journal.

This is an open-access article distributed under the terms and conditions of the Creative Commons Attribution license (http://creativecommons.org/licenses/by/4.0/). 